\title{
INTEGRASI MODEL PCK PADA PENGEMBANGAN MODUL MATEMATIKA UNTUK MENGEMBANGKAN KETERAMPILAN BERPIKIR KRITIS
}

\author{
Hapsari Dika Pratiwi1 ${ }^{\mathrm{a}}$, Riawan Yudi Purwoko2 ${ }^{\mathrm{b}}$, Erni Puji Astuti3 ${ }^{\mathrm{c}}$ \\ a FKIP/Pendidikan Matematika/Universitas Muhammadiyah Purworejo, Jawa Tengah, 54152, Indonesia \\ b FKIP/Pendidikan Matematika/Universitas Muhammadiyah Purworejo, Jawa Tengah, 54117, Indonesia \\ c FKIP/Pendidikan Matematika/Universitas Muhammadiyah Purworejo, Jawa Tengah, 54114, Indonesia \\ ${ }^{\mathrm{x}}$ Corresponding author: E-mail addresses: hapsari.tiwi@gmail.com
}

\begin{abstract}
The purpose of this study is to compile a mathematical module that integrates Pedagogical Content Knowledge (PCK) models to develop critical thinking skills of high school students. The development model used in this study is the Plomp development model. Plomp development model consists of 4 stages, namely (a) Investigation Stage, (b) Designing Stage, (c) Realization / Construction Stage, (d) Test Stage, Evaluation, and Revision. The method used to collect data is questionnaire, observation, test of learning outcomes, and documentation. The instruments used were validity sheets, practicality sheets, and effectiveness sheets. Modules are said to be feasible if it meets the criteria of valid, practical and effective. Data analysis techniques used are qualitative descriptive analysis techniques. After data analysis, product validity assessment was categorized as very good with an average percentage of $85,15 \%$, practicality assessment categorized as good with a percentage of 76,67\%, and effectiveness assessment categorized as good with a percentage of $64,5 \%$. Based on this, it can be concluded that the mathematics module that integrates the PCK model is appropriate to be used to develop critical thinking skills of senior high school students.
\end{abstract}

Keywords: Integration of PCK Model, Development, Mathematics Module, Critical Thingking.

\section{PENDAHULUAN / INTRODUCTION}

Matematika adalah ratu ilmu pengetahuan. Mulai dari kehidupan sehari-hari hingga bahasa Indonesia bahkan membutuhkan matematika. Namun, semua itu terkadang tidak disadari dengan mengasumsikan bahwa matematika itu sulit dipelajari. Faktor yang membuat matematika sulit bukan karena materi tetapi karena asumsi siswa itu sendiri yang mengakibatkan itu menjadi sulit dalam belajar matematika. Kesulitan-kesulitan ini menyebabkan pemahaman siswa yang kurang luas tentang materi karena siswa lebih sering menghafal. Kebiasaan menghafal sulit untuk mengembangkan keterampilan berpikir matematika. Selain itu, matematika tampak sulit karena kurangnya model yang tepat yang digunakan oleh guru ketika mengajar. Saat ini, pendidikan di Indonesia masih terombang- ambing dengan adanya pembaruan kurikulum yang tidak tetap, terutama dalam mata pelajaran matematika. Untuk mengurangi hal tersebut harus didukung dengan proses pembelajaran yang baik. Proses pembelajaran yang baik harus diimbangi oleh kemampuan guru yang baik pula dalam mengajar. Seorang guru profesional dan calon guru harus memiliki pengetahuan tentang model Pedagogical Content Knowledge (PCK).

Menurut Hill dalam Lannin, J. K. et al (2013) Utilized a PCK framework that included three components: knowledge of content and students (KCS), knowledge of curriculum, and knowledge of content and teaching (KCT). We adapted the framework of Magnusson dalam Lannin, J. K. et al (2013) is including knowledge of assessment. Dari keempat komponen tersebut harus dipahami semua oleh seorang guru karena saling berkaitan antar komponen-komponen ini. Knowledge of content and students yaitu sejauh mana pemahaman konsep siswa pada matematika seperti pengetahuan bahwa siswa mengalami kesulitan mengembangkan makna dari notasi atau simbol matematika, knowledge of content and teaching merupakan langkah apa yang digunakan dalam pembelajaran matematika seperti pengetahuan mengkaitkan beberapa materi matematika sehingga dapat membangun pemahaman 
siswa, knowledge of curriculum yaitu pengetahuan tentang bagaimana ide-ide matematika berkembang dalam satu unit atau di tingkat kelas, dan knowledge of assessment yaitu pengetahuan tentang apa ide-ide matematika yang penting untuk dinilai. Seorang guru yang hanya memiliki satu dari tiga komponen tersebut akan ketimpangan dalam proses pembelajaran apabila seorang guru hanya memiliki kemampuan untuk mengajar saja tanpa mengikuti kurikulum yang digunakan maka tujuan pembelajaran tidak akan tercapai.

Selain itu, seorang guru matematika, selain harus memiliki pengetahuan tentang model PCK, ia juga harus memperhatikan perangkat pembelajaran yang akan digunakan seperti media pembelajaran, bahan ajar, Lembar Kerja Siswa (LKS), Rencana Pelaksanaan Pembelajaran (RPP), dan lainnya untuk mendukung proses pembelajaran agar siswa merasa lebih mudah. Bahan ajar yang sering digunakan oleh guru yaitu buku guru, buku siswa yang diperoleh dari pemerintah, sedangkan proses pembelajaran yang diharapkan oleh siswa adalah proses pembelajaran yang dapat memudahkan siswa dalam memahami materi. Penjelasan dari guru tidak cukup untuk memudahkan siswa memahami materi. Pengadaan modul jarang dilakukan, meskipun modul dapat digunakan secara mandiri oleh siswa dengan maksud modul merupakan bahan ajar yang disusun secara sistematis dengan bahasa yang mudah dipahami oleh siswa sesuai dengan tingkat pengetahuan dan usia mereka (Prastowo dalam Kartiningtyas, 2012).

Dalam pengimplementasian kurikulum 2013, tidak cukup hanya menggunakan modul, tetapi harus didukung dengan perangkat lain seperti LKS dan RPP karena akan sangat membantu proses pembelajaran siswa di kelas. Di samping itu, karena kurangnya waktu belajar di kelas dengan materi yang sangat luas sehingga kurang berlatih untuk mengembangkan keterampilannya. Untuk mengembangkan keterampilan, lebih banyak pemikiran dibutuhkan. Pemikiran untuk memilih rumus yang tepat, mengaplikasikan rumus, dan menarik kesimpulan yang benar. Untuk itu, keterampilan berpikir kritis perlu dikembangkan. Menurut Ennis (dalam Sunaryo, Y., 2014: 45) bahwa dalam berpikir kritis terdapat enam indikator yaitu focus (fokus), Reason (alasan), inference (menyimpulkan), situasion (situasi), clarity (kejelasan), and overview (pandangan menyeluruh).

Penyisipan aspek model PCK yang dimiliki oleh seorang guru dalam modul matematika dimaksudkan agar siswa tidak hanya dapat belajar di kelas, namun juga dapat belajar secara mandiri dengan panduan yang ada dalam modul dan mempraktekkan keterampilan berpikir kritis dengan mengerjakan pertanyaan-pertanyaan di modul. Dalam pembelajaran matematika, perlu dikembangkan modul seperti itu untuk mendukung tercapainya tujuan pembelajaran yang ingin dicapai. Oleh karena itu, peneliti akan mengembangkan modul matematika yang mengintegrasikan model Pedagogical Content Knowledge (PCK) untuk mengembangkan keterampilan berpikir kritis siswa kelas XI dalam materi barisan dan mengetahui kelayakannya.

\section{KAJIAN PUSTAKA /LITERATURE REVIEW}

Modul matematika adalah komponen penting dalam proses pembelajaran matematika yang memuat materi pelajaran matematika yang disesuaikan dengan kompetensi isi dan kompetensi dasar yang tercantum dalam silabus pembelajaran. Modul matematika digunakan dalam proses pembelajaran matematika sesuai dengan tingkatan dan kebutuhannya guna mencapai tujuan pembelajaran yang optimal. Tujuan dari pembuatan modul ini adalah untuk mengembangkan keterampilan berpikir kritis. Adapun indikator berpikir kritis (Ennis dalam Sunaryo, 2014) yaitu focus (fokus), Reason (alasan), inference (menyimpulkan), situasion (situasi), clarity (kejelasan), and overview (tinjauan/ pemeriksaan). Sedangkan, Pedagogical Content Knowledge (PCK) adalah kompetensi yang dimiliki seorang guru meliputi pengetahuan yang dimiliki guru tersebut, mengikuti perkembangan kurikulum, kemampuan dalam mengajar siswa, dan bagaimana mengelola kelas agar siswa dapat memahami pelajaran dengan mudah. Modul matematika yang mengintegrasi model PCK ini mencakup materi barisan yang nantinya pada modul yang dibuat mengintegrasi 
komponen-komponen dari model PCK. Komponen-komponen dari model PCK dapat digambarkan sebagai berikut.

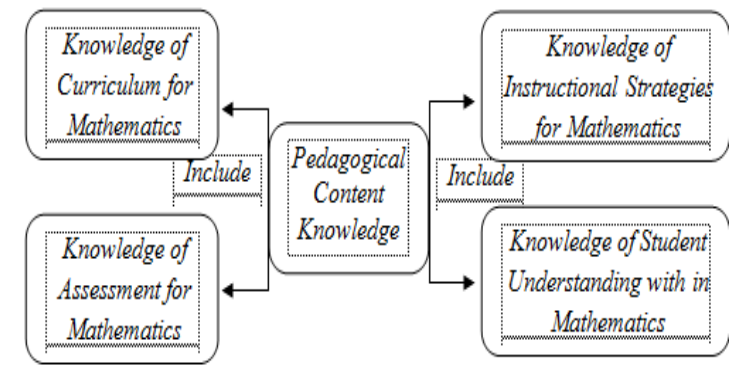

Gambar 1 Model PCK pada pembelajaran matematika (Lannin, 2013)

Knowledge of Curriculum for Mathematics Mengenai pengetahuan kurikulum yang dimuat dalam modul matematika ini dengan kesesuaian materi dalam modul yang diatur sesuai dengan cakupan materi yang terdapat pada silabus yang digunakan pada sekolah yang akan diteliti. Materi yang ada dalam modul dimulai dari awal, yang setiap materinya saling berurutan dan berkaitan dengan materi selanjutnya disajikan dalam Learning Trajectory. Tujuan pembelajaran juga dimuat dalam modul yang disesuaikan dengan kompetensi isi (KI) dan kompetensi dasar (KD) agar pembelajaran dapat berjalan dengan lancar sesuai kurikulum yang berlaku.

\section{Knowledge of Student Understanding within} Mathematics

Untuk mengetahui bagaimana kondisi siswa terkait dalam pembelajaran matematika di kelas, maka perlu adanya pertanyaanpertanyaan ringan untuk sekedar mengingat kembali pemahaman siswa tentang materi terkait yang terdapat pada modul kemudian diberikan latihan soal yang berupa uraian. Dalam modul juga terdapat materi yang menghubungkan antara matematika dengan gambaran masalah kehidupan nyata untuk lebih meyakinkan siswa dalam menemukan sebuah konsep matematika (Believe Understanding). Di samping itu, guru juga dapat meyakinkan siswa dengan memberikan motivasi di awal pembelajaran atau di sela-sela pembelajaran. Sehingga dapat ditemukan kesulitan apa yang dialami siswa dalam pembelajaran matematika di kelas dan bagaimana pemahaman siswa terhadap pembelajaran matematika di kelas.

Knowledge of Instructional Strategies for Mathematics
Pengetahuan tentang langkah strategis dalam pembelajaran matematika yang akan dimuat dalam modul matematika adalah materi yang disajikan secara runtut, contoh soal dengan penyelesaian yang jelas dan dilengkapi dengan latihan soal yang nantinya akan menghasilkan jawaban siswa yang dapat memicu keterampilan berpikir kritis siswa berkembang. Soal-soal dalam modul matematika dapat dikerjakan secara individu maupun berkelompok menggunakan model cooperative learning, sehingga akan melibatkan siswa secara aktif untuk saling berkomunikasi dalam mendiskusikan pemecahan masalah matematika. Modul matematika ini disusun dengan pendekatan kontrukstivistik. Pemecahan masalah yang dilakukan berulang kali akan menumbuhkan rasa tertarik pada siswa karena pengalamanpengalaman yang dialaminya selama menyelesaikan masalah.

\section{Knowledge of Assessment for Mathematics}

Perlunya penilaian dalam modul ini dimaksudkan sebagai pengukuran hasil belajar siswa setelah mengikuti proses pembelajaran di kelas. Penilaian dalam modul ini berupa soal-soal yang bersifat esai maupun uraian dengan harapan siswa dapat secara mendalam menuangkan pemahamannya dalam menyelesaikan masalah. Jadi, penilaian tidak didasarkan pada hasil yang diperoleh siswa melainkan bagaimana proses siswa tersebut dalam menyelesaikan suatu masalah. Dapat dikatakan bahwa pengukuran hasil belajar yang digunakan dalam modul ini adalah penilaian autentik (Authentic Assessment). Penilaian tersebut dilakukan untuk melihat proses berpikir siswa dalam menyelesaikan masalah setelah mengikuti proses pembelajaran di kelas.

Dari uraian di atas, integrasi model PCK pada pengembangan modul matematika berupa bahan ajar yang digunakan untuk memfasilitasi siswa dalam pembelajaran matematika pada materi barisan. Modul ini memuat empat karakteristik yaitu knowledge of Curriculum for Mathematics dengan learning trajectory, knowledge of Student Understanding within Mathematics dengan believe understanding, knowledge of Instructional Strategies for Mathematics dengan Constructivistic learning, dan knowledge of Assessment for Mathematics dengan Authentic Assessment. Pada setiap karakteristik tersebut diintegrasi sesuai 
kurikulum, KI, KD, dan tujuan pembelajaran yang akan dicapai. Dalam proses pembelajaran ini siswa akan dilatih kemandiriannya dalam menyelesaikan masalah dan dituntut mampu menggunakan segala kemampuannya untuk terjun langsung ke dalam permasalahan dan memenuhi indikator berpikir kritis sehingga siswa dikatakan mampu berpikir kritis.

\section{METODOLOGI / METHODS}

a. Subjek dan Objek Penelitian

Subjek penelitian ini adalah siswa kelas XI MIPA 4 SMAN 7 Purworejo semester genap tahun pelajaran 2017/2018 berjumlah 31 siswa. Objek dalam penelitian ini adalah modul matematika.

b. Desain Penelitian

Metode yang digunakan dalam penelitian ini adalah metode penelitian dan pengembangan (Research and Development) dengan menggunakan model Plomp. Model pengembangan Plomp terdiri atas 4 tahap, yaitu (1) Tahap Investigasi, (2) Tahap Perancangan (design), (3) Tahap Realisasi/ Konstruksi, (4) Tahap Tes, Evaluasi, dan Revisi.

1. Tahap Investigasi

Salah satu unsur penting dalam proses desain adalah mendefinisikan masalah (defining the problem). Investigasi unsur-unsur penting adalah mengumpulkan dan menganalisis informasi, definisi masalah dan rencana lanjutan dari proyek. Kegiatan yang dilakukan pada tahap ini mengkaji: (1) pendekatan kontruktivisme, (2) teori-teori belajar, (3) teori tentang model PCK, (4) budaya siswa SMAN 7 Purworejo kelas XI, (5) kebutuhan lapangan tentang pentingnya modul matematika dalam pembelajaran, dan (6) mengkaji materi barisan. Selain itu pada tahap ini juga dilakukan identifikasi terhadap kondisi siswa meliputi kemampuan, pengalaman, dan analisis materi, yaitu mengidentifikasi, merinci, dan menyusun konsep secara sistematis untuk pengorganisasian materi pelajaran. Dengan pertimbangan tersebut akhirnya dirancang modul matematika yang mengintegrasikan model PCK.

2. Tahap Perancangan (Design)
Pada tahap ini dirancang modul matematika dengan pendekatan kontruktivisme dengan mengoptimalkan keaktifan dan pengalaman siswa. Kegiatan yang dilakukan pada tahap ini meliputi: (1) merancang sintaks pembelajaran yang menggunakan masalah yang dekat dengan kehidupan sehari-hari siswa di SMAN 7 Purworejo dan menyisipkan latihan soal dilengkapi penyelesaian secara urut atau tahapan pemecahan masalah yang diharapkan dapat mengoptimalkan keaktifan siswa, (2) merancang prinsip reaksi, yaitu memberikan gambaran kepada guru bagaimana harus memberikan intervensi kepada siswa serta bagaimana memandang dan merespon setiap perilaku yang ditunjukkan oleh siswa selama pembelajaran, (3) merancang sistem pendukung, yaitu perangkat pembelajaran (seperti buku siswa, modul, dan Rencana Pelaksanaan Pembelajaran/RPP), fasilitas belajar, dan media yang diperlukan dalam pembelajaran, (4) merancang dampak dari pembelajaran. Dampak disini ada dua macam yaitu dampak instruksional dan dampak pengiring. Dampak instruksional adalah dampak yang merupakan akibat langsung dari pembelajaran, seperti berkembangnya keterampilan berpikir siswa dilihat dari proses pemecahan masalah, sedangkan dampak pengiring adalah akibat tidak langsung dari pembelajaran, seperti sifat demokratis, inovatif, kompetitif, dan sebagainya. Hasil pada fase ini masih berupa ide-ide awal atau draf awal.

3. Tahap Realisasi/Konstruksi

Pada tahap ini dibuat/disusun suatu modul matematika yang terintegrasi model PCK sebagai lanjutan dari tahap desain, sehingga menghasilkan prototipe 1, yaitu rancangan yang berisi komponen-komponen modul yang disebutkan pada bagian (2) di atas. Prototipe 1 inilah yang akan terus dikembangkanpada tahap pengembangan berikutnya.

4. Tahap Tes, Evaluasi, dan Revisi

Tahap ini difokuskan pada dua hal, yakni: (1) memvalidasi dan (2) mengadakan uji coba lapangan prototipe 1 tentang modul matematika 
beserta perangkat yang telah disusun. Penelitian ini hanya difokuskan pada memvalidasi modul beserta perangkatnya secara teoritis dan uji coba terbatas. Produk yang akan diperoleh dalam penelitian ini adalah prototipe yang memenuhi kriteria valid. Adapun kegiatan yang dilakukan pada tahap ini secara rinci adalah sebagai berikut.

a) Memvalidasi Modul

Kegiatan yang dilakukan pada waktu memvalidasi modul adalah sebagai berikut.

1) Meminta pertimbangan validator tentang kelayakan prototipe modul matematika yang telah disusun. Untuk kegiatan ini diperlukan instrumen berupa lembar validasi yang diserahkan kepada validator. Validator terdiri dari ahli tentang pendekatan kontruktivisme dan model PCK, dan media (modul pembelajaran).

2) Melakukan analisis terhadap hasil validasi dari validator. Jika hasil analisis menunjukkan:

(a) valid tanpa revisi, maka kegiatan selanjutnya adalah uji coba lapangan.

(b) valid dengan revisi kecil, maka dilakukan revisi, setelah itu ujicoba lapangan tentang keterbacaan perangkat secara terbatas. Berdasarkan analisis hasil uji coba terbatas dilakukan revisi, sehingga diperoleh prototipe 2. Setelah itu dilakukan uji coba lapangan dengan skala yang lebih besar.

(c) tidak valid, maka dilakukan revisi besar sehingga diperoleh prototipe Kemudian kembali pada kegiatan (a), yaitu meminta pertimbangan ahli. Disini ada kemungkinan terjadi siklus.

b) Mengadakan uji coba lapangan

Uji coba lapangan dilakukan untuk melihat keterbacaan perangkat yang dikembangkan, respon siswa, dan ketuntasan hasil belajar secara klasikal.

c. Alur Pengolahan Data

Metode yang dipakai untuk mengumpulkan data dalam penelitian ini ialah metode angket, observasi, tes hasil belajar, dan dokumentasi. Angket yang digunakan dalam penelitian ini berupa angket penilaian untuk ahli materi dan media pengembangan modul, angket penilaian diri dan penilaian teman. Observasi yang dilakukan merupakan observasi terstruktur, yaitu observasi yang telah dirancang secara sistematis, tentang apa yang akan diamati, kapan dan di mana tempatnya (Sugiyono, 2011). Dokumentasi yang dilakukan dalam penelitian ini bertujuan untuk memperkuat data yang ada dan foto-foto bukti penelitian telah dilakukan. Instrumen yang digunakan dalam penelitian ini adalah silabus, RPP, modul yang dikembangkan, lembar penilaian untuk ahli, lembar kepraktisan untuk guru, dan lembar kepraktisan untuk siswa. Teknik analisis data yang digunakan adalah teknik analisis deskriptif kualitatif yaitu memaparkan hasil pengembangan produk yang berupa modul matematika yang mengintegrasi model PCK, setelah dilakukan uji kelayakan produk, meliputi Uji kevalidan, kepraktisan, dan keefektifan produk sehingga dapat diimplementasikan pada mata pelajaran matematika. Pada penelitian ini, angket yang digunakan menggunakan skala Likert. Kemudian data yang terkumpul diproses dengan cara dijumlahkan, dibandingkan dengan jumlah yang diharapkan sehingga diperoleh persentasenya. Data yang terkumpul dianalisis dengan menggunakan teknik analisis deskriptif kualitatif yang diungkapkan dalam distribusi skor dan presentase, langkah selanjutnya mendeskripsikan dan mengambil kesimpulan tentang masingmasing indikator. Kesesuaian aspek dalam pengembangan media pembelajaran dapat menggunakan tabel berikut.

Tabel 1. Skala Persentase Kelayakan Produk

\begin{tabular}{|c|c|}
\hline Interval Skor & \multicolumn{1}{|c|}{ Kriteria } \\
\hline $81 \%-100 \%$ & $\begin{array}{l}\text { Sangat Valid, } \\
\text { Praktis, dan Efektif }\end{array}$ \\
\hline
\end{tabular}




\begin{tabular}{|c|l|}
\hline $61 \%-80 \%$ & $\begin{array}{l}\text { Valid, Praktis, dan } \\
\text { Efektif }\end{array}$ \\
\hline $41 \%-60 \%$ & $\begin{array}{l}\text { Cukup Valid, } \\
\text { Praktis, dan Efektif }\end{array}$ \\
\hline $21 \%-40 \%$ & $\begin{array}{l}\text { Kurang Valid, } \\
\text { Praktis, dan Efektif }\end{array}$ \\
\hline $0-20 \%$ & $\begin{array}{l}\text { Tidak Valid, } \\
\text { Praktis, dan Efektif }\end{array}$ \\
\hline
\end{tabular}

Riduwan (2013: 15)

\section{HASIL DAN PEMBAHASAN/ FINDINGS AND DISCUSSION}

Berdasarkan prosedur penelitian yang telah dikemukakan, yakni dengan menggunakan model Plomp pada pengembangan modul matematika yang mengintegrasikan model Pedagogical Content Knowledge (PCK) untuk mengembangkan keterampilan berpikir kritis siswa SMA terdiri dari 4 tahap, meliputi: tahap investigasi, tahap perancangan, tahap realisasi/konstruksi, tahap tes, evaluasi, dan revisi. Tahapantahapan tersebut secara terperinci akan dijelaskan sebagai berikut.

Pada tahap investigasi untuk mengetahui kebutuhan untuk modul matematika yang dikembangkan, dilakukan analisis terhadap sumber belajar yang digunakan, model pembelajaran yang diterapkan dan kondisi kelas selama pembelajaran dilakukan. Dari hasil analisis dinyatakan bahwa bahan ajar yang digunakan adalah buku teks, sementara model pembelajaran yang digunakan adalah metode tanya jawab dan diskusi. Sedangkan pembelajaran yang mengarahkan siswa pada berpikir kritis masih kurang berkembang, sehingga kemampuan menguasai materi biasa dilakukan dengan menggunakan metode hafalan. Pada tahap ini peneliti memilih materi barisan untuk digunakan dalam modul yang akan dirancang.

Pada tahap perancangan (design) dilakukan dengan menyiapkan rancangan sintaks pembelajaran, prinsip reaksi, sistem pendukung, dan dampak pembelajaran. Materi yang disusun mengikuti langkahlangkah keterampilan berpikir kritis yaitu fokus, situasi, kejelasan, alasan, simpulan, dan pemeriksaan atau tinjauan.

(a) Focus (Fokus)

Pada tahap ini modul didesain agar siswa dapat memanfaatkan kemampuan mereka untuk fokus pada masalah yang ada. Salah satu kegiatan yang dilakukan adalah menulis apa yang diketahui dan apa yang ditanyakan tentang masalah tersebut.

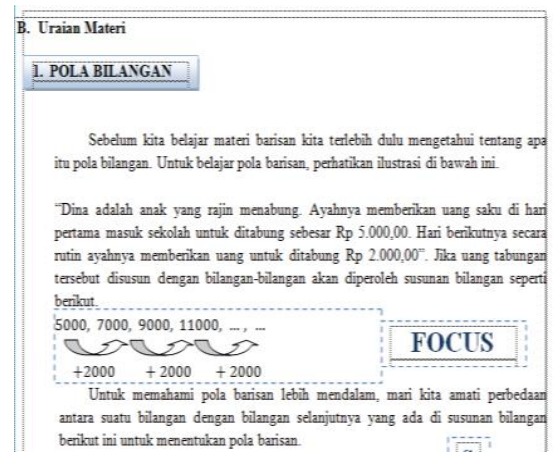

Gambar 2 Fokus permasalahan

(b) Situation (Situasi)

Pada tahap ini modul didesain agar siswa setelah menemukan fokus masalah dapat menggunakan konsep yang mereka miliki sebelumnya.

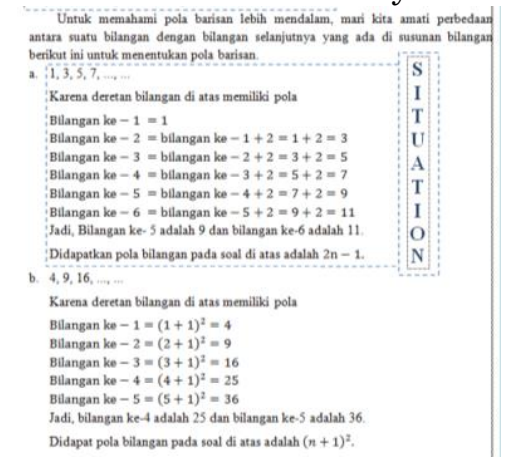

Gambar 3 Langkah menentukan pola bilangan

(c) Clarity (Kejelasan)

Pada tahap ini modul didesain agar pemahaman siswa lebih terkonsep dengan mengerjakan soal yang rumpang.
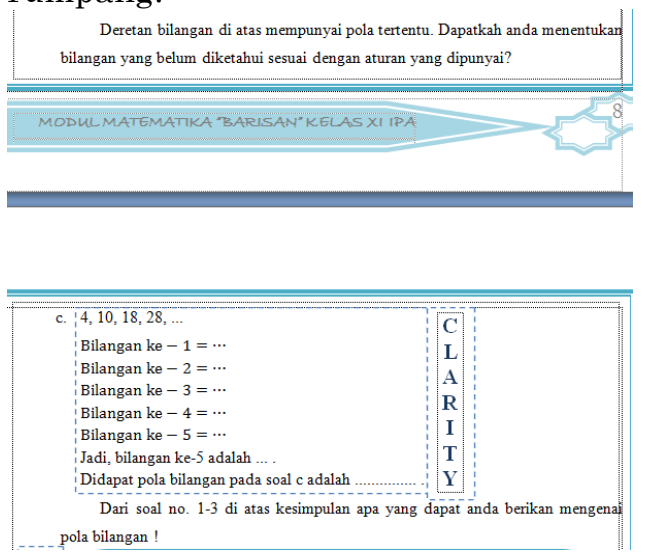

Gambar 4 Mengisi kolom jawaban yang

(d) Reason (Alasan) rumpang

Pada tahap ini modul didesain agar siswa mampu memberikan alasan atau argumen mengapa siswa tersebut memilih penyelesaian tersebut. 

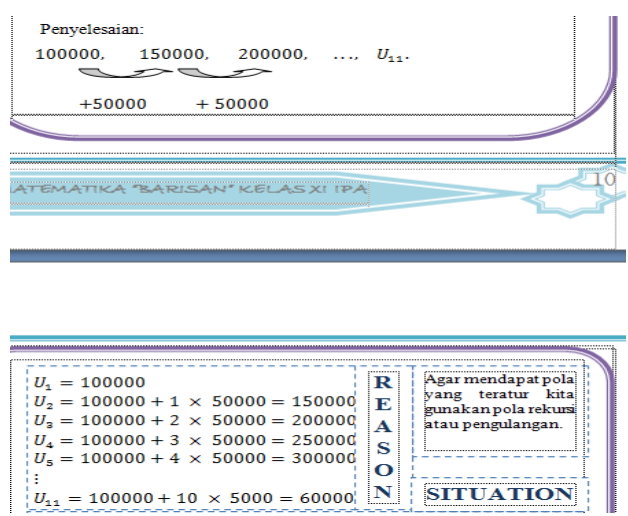

Gambar 5 Alasan dari setiap langkah

(e) Inference (Simpulan)

Pada tahap ini modul didesain agar siswa mampu mengoperasikan rumus, siswa mendapatkan hasil akhir dari suatu algoritma kemuadian siswa dapat menulis kesimpulan dari jawaban atas apa yang ia kerjakan sesuai dengan apa yang ditanyakan dalam pertanyaan.
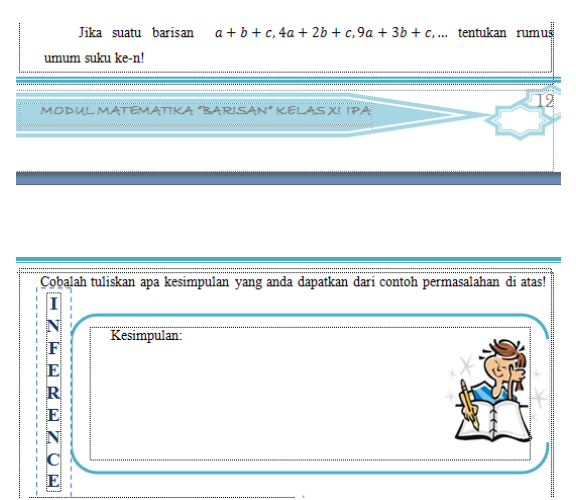

Gambar 6 Menulis kesimpulan dari pemahaman

(f) Overview (pemeriksaan atau tinjauan) Tahapan akhir pada proses pembelajaran, siswa dapat memeriksa kebenaran jawaban dari pekerjaan dan menilai hasil pekerjaan mereka.

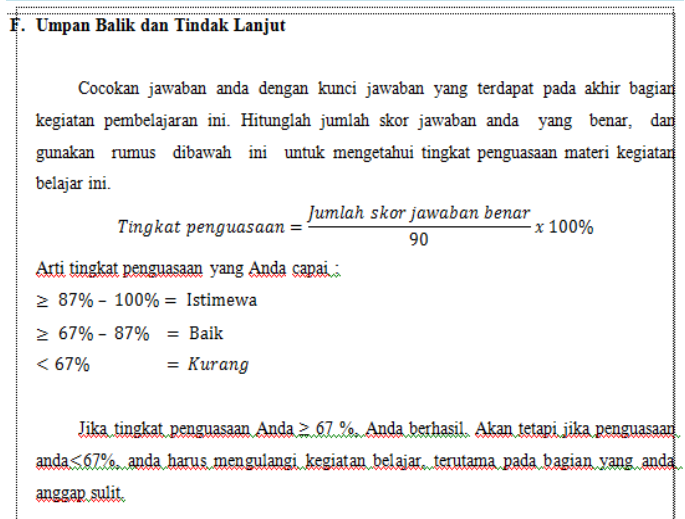

Gambar 7 Menilai hasil pekerjaan sendiri
Sementara modul yang disusun mengintegrasikan model PCK meliputi 4 komponen, yaitu knowledge of curiculum for mathematics terintegrasi pada KI, KD, peta konsep, tujuan pembelajaran, dan daftar isi untuk mengetahui keruntutan materi, knowledge of student understanding with in mathematics terintegrasi pada pemaparan materi yang disajikan secara runtut dilengkapi kolom kesimpulan untuk mengetahui sejauh mana pemahaman konsep siswa setelah membaca materi, knowledge of instructional strategies for mathematics terintegrasi pada pembahasan contoh soal untuk lebih memudahkan siswa memahami konsep barisan, dan soal latihan, dan knowledge of assassment for mathematics terintegrasi pada evaluasi yang diberikan dalam modul.

Pada tahap realisasi/konstruksi adalah penyusunan modul matematika yang mengintegrasikan model PCK, modul pegangan guru, RPP, dan instrumen penelitian. RPP disusun sesuai dengan silabus SMA kelas XI menggunakan K-13. Sedangkan instrumen penelitian yang disusun adalah angket penilaian kepraktisan untuk guru, dan instrumen tes hasil belajar.

Pada tahap tes, evaluasi, dan revisi dalam penelitian ini adalah melakukan validasi modul dan uji lapangan. Kegiatan dalam memvalidasi modul meliputi: penilaian modul oleh ahli materi dan ahli media, kemudian revisi modul dilakukan apabila terdapat saran dari validator. Berdasarkan aspek kualitas isi, ketepatan, keterampilan berpikir kritis, bahasa, aspek PCK dan evaluasi dalam modul matematika ini dikategorikan baik, sehingga dari kriteria yang diinginkan peneliti sesuai dengan penilaian oleh ahli materi. Dalam hal materi, modul matematika ini dapat digunakan sebagai media pembelajaran. Sedangkan berdasarkan aspek format, organisasi, daya tarik, ukuran huruf dan bahasa dikategorikan baik menurut ahli media. Sehingga menurut ahli media modul matematika yang mengintegrasikan model PCK dapat digunakan sebagai media belajar siswa. Hal tersebut terjadi karena penilaian kevalidan produk dikategorikan sangat baik dengan persentase rata-rata $85,15 \%$.

Tahapan berikutnya adalah uji lapangan dilakukan di SMAN 7 Purworejo pada siswa kelas XI MIPA 4, dikelas tersebut pembelajaran dilakukan 4 kali pertemuan 
sesuai RPP yang telah disusun. Pertemuan ini dimulai pada 9 Mei 2018. Setelah menyelesaikan pembelajaran menggunakan modul matematika, pada pertemuan selanjutnya tes hasil belajar dilakukan untuk mengetahui efektivitas produk dan angket kepraktisan diberikan kepada guru untuk mengetahui kualitas modul. Penilaian kepraktisan dikategorikan baik dengan persentase $76,67 \%$, dan penilaian efektivitas dikategorikan baik dengan persentase $64,5 \%$. Berikut analisis hasil pekerjaan siswa sehingga dikatakan mampu berpikir kritis.

a. Fokus

Dalam memahami masalah adalah menentukan apa yang menjadi focus (fokus) dalam masalah tersebut. Hal ini dilakukan agar pekerjaan menjadi lebih efektif, karena tanpa mengetahui fokus permasalahan, kita akan membuang banyak waktu.

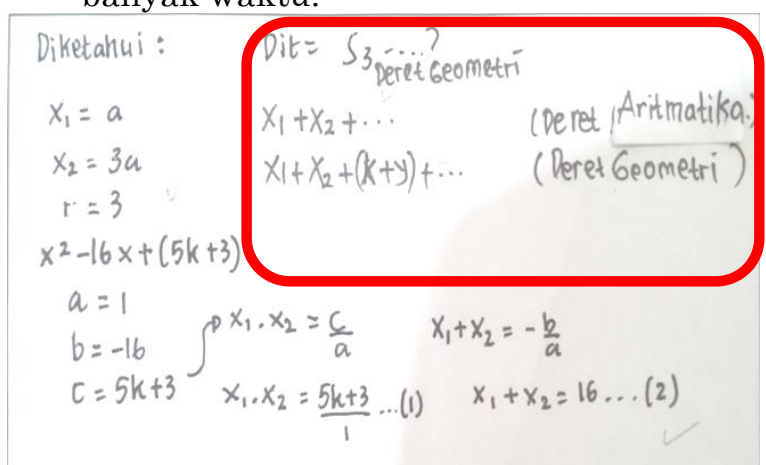

Gambar 8 Hasil pekerjaan siswa

Dari gambar 4.11, siswa dapat menuliskan apa yang diketahui dan apa yang ditanyakan dari soal yang ada. Hal ini menunjukkan bahwa siswa dapat mengaitkan antar konsep aritmatika dimana pada soal yang diketahui adalah deret aritmatika sedangkan pertanyaannya adalah deret geometri.

b) Situasi dan kejelasan

Menerapkan konsep yang dimiliki sebelumnya untuk menyelesaikan soal secara runtut.

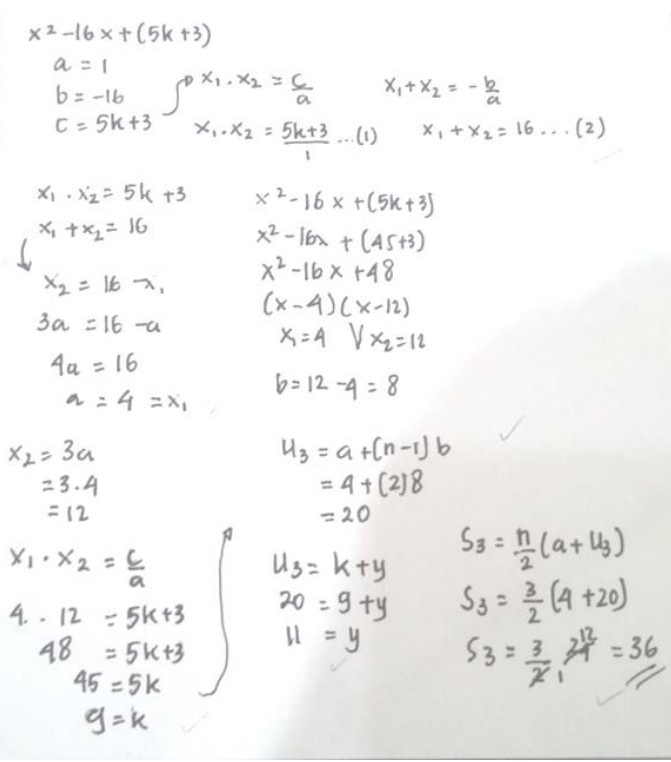

Gambar 9 Hasil pekerjaan siswa

Dari gambar 4.12, siswa dapat menuliskan penyelesaian yang dilengkapi dengan langkah-langkah yang jelas dan runtut. Hal ini menunjukkan bahwa penguasaan konsep yang dimilikinya baik karena sulit bagi siswa yang belum paham untuk mengaplikasikan rumus yang ada.

c) Alasan

Reason (alasan) yaitu memberikan alasan/argumen terhadap jawaban atau menguraikan jawaban atau gagasan yang lebih rinci yang diberikan.

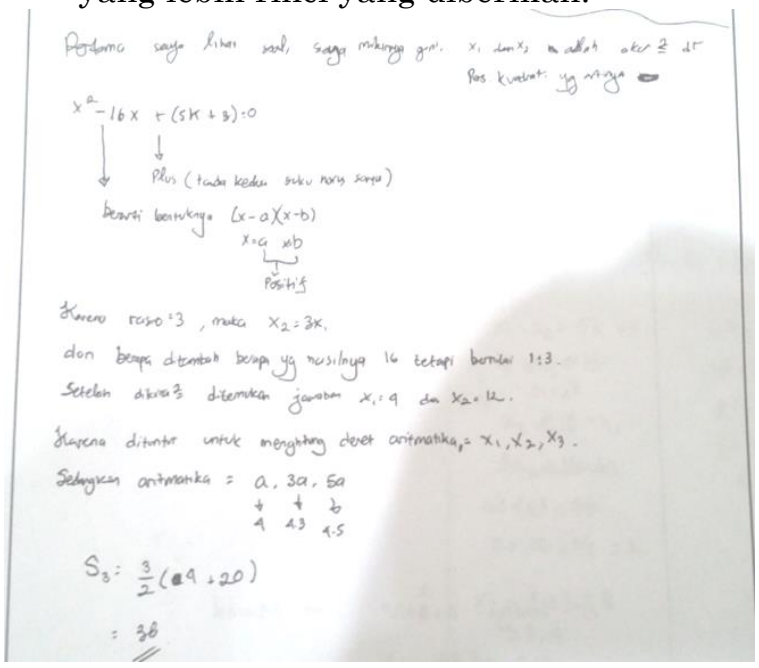

Gambar 10 Hasil pekerjaan siswa

Dari gambar 4.13, siswa dapat memberikan argumen tentang menemukan akar-akar dari persamaan kuadrat dan mengubah barisan aritmatika menjadi barisan geometri.

d) Simpulan 
Inference (simpulan) yaitu memperkirakan simpulan yang akan didapat.

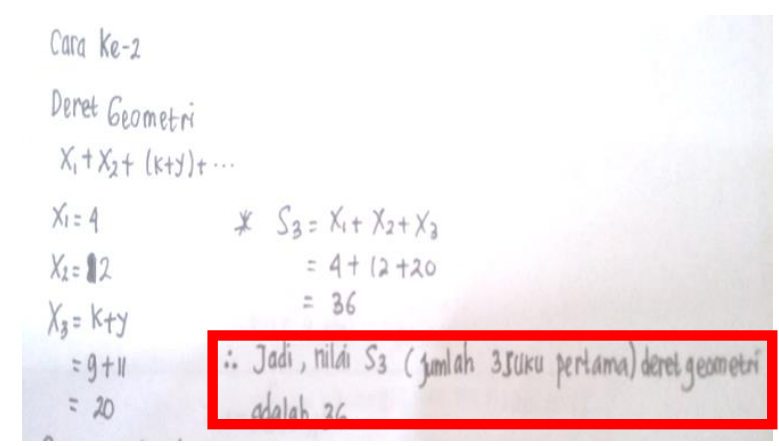

Gambar 11 Hasil pekerjaan siswa

Dari gambar 4.14, siswa dapat menarik kesimpulan dari apa yang ditanyakan, yaitu jumlah dari 3 suku pertama deret geometri adalah 36. Hal tersebut terbukti benar karena dikerjakan dengan cara lain dan menemukan jawaban yang sama yaitu 36 .

e) Pemeriksaan

Pada tahap ini siswa dapat memeriksa kebenaran jawaban, yaitu jumlah dari 3 suku pertama deret geometri adalah 36 .

Berdasarkan analisis di atas sesuai dengan tujuan penelitian ini bahwa modul matematika yang dikembangkan layak digunakan untuk mengembangkan keterampilan berpikir kritis siswa SMA. penelitian tanpa revisi. Modul matematika yang dikembangkan dinilai valid oleh ahli. Selanjutnya pembelajaran dilakukan sesuai dengan RPP, kemudian penilaian kepraktisan yang dilakukan oleh guru dikategorikan baik dengan presentase $76,67 \%$, dan pada tahap akhir dari pembelajaran diberikan tes hasil belajar diperoleh persentase $64,5 \%$ dengan kategori baik sehingga dapat disimpulkan bahwa modul matematika yang mengintegrasikan model PCK layak digunakan untuk mengembangkan keterampilan berpikir kritis siswa SMA.

b. Saran

Berdasarkan hasil penelitian yang diperoleh, maka saran yang diberikan peneliti adalah sebagai berikut.

1. Pengembangan modul matematika yang mengintegrasi model Pedagogical Content Knowledge (PCK) untuk mengembangkan keterampilan berpikir kritis diharapkan dapat digunakan pada saat jam efektif sekolah.

2. Pengembangan modul matematika yang mengintegrasi model Pedagogical Content Knowledge (PCK) masih memerlukan peran guru dalam memberikan bantuan seperlunya kepada siswa, sehingga pemahaman siswa akan menjadi lebih baik.

\section{DAFTAR PUSTAKA / REFERENCES}

Hasnunidah, N. 2012. Keterampilan Berpikir Kritis Siswa SMP Pada Pembelajaran Ekosistem Berbasis Konstruktivisme Menggunakan Media Maket. Jurnal Pendidikan MIPA, Vol. 13, No. 1., hal 64-74.

Indrasari, N. 2015. Pengembangan Modul Fluida Statis berbasis Kecerdasan Majemuk dan Pedagogical Content Knowledge (PCK) untuk Meningkatkan Kemampuan Berpikir Kritis Siswa. Artikel Mahasiswa Universitas Negeri Malang. Diunduh pada 27 Desember 2017, https://www.google.com/url?sa=t\&source=web\&rct=j\&url=http://fisik a.um.ac.id/download/doc_download/770 -noraindrasariendangpaguss.html 
Kartiningtyas, M. 2012. Pengaruh Penggunaan Modul Pembelajaran IPA terhadap Hasil Belajar Siswa Kelas IV SD Semester II tahun ajaran 2011/ 2012. Skripsi Mahasiswa Program Studi PGSD Universitas Kristen Satya Wacana. Diunduh pada 17 November 2017, https://www.google.co.id/url?sa=t\&sour ce $=$ web\&rct

=j\&url=http://repository.uksw.edu

Lannin, J. K. Et al. 2013. The development of beginning mathematics teacher pedagogical content knowledge. J Math Teacher Education.

DOI 10.1007/s10857-013-9244-5.

Loughran, J. et al. 2012. Understanding and Developing Science Theacher's Pedagogical Content Knowledge. Rotterdam: Sense Publisher.

Novikasari, I. 2009. Pengembangan Kemampuan Berpikir Kritis Siswa melalui Pembelajaran Matematika Open-ended di Sekolah Dasar. Jurnal Pemikiran Alternatif Kependidikan, Vol. 14, No. 2.

Peniati. 2012. Pengembangan Modul Mata Kuliah Strategi Belajar Mengajar IPA Berbasis Hasil Penelitian Pembelajaran. Jurnal Pendidikan IPA Indonesia, Volume 1: 8-15.

Riduwan. 2013. Skala Pengukuran VariabeVariabel Penelitian. Bandung: Alfabeta.

Rochmad. 2012. Desain Model Pengembangan Perangkat Pembelajaran Matematika. Jurnal Kreano, Vol 3, Nomor 1, hal 66-68.

Sugiyono. 2011. Metode Penelitian Kuantitatif Kualitatif dan $R \& D$. Bandung: Alfabeta.

Sunaryo, Y. 2014. Model Pembelajaran Berbasis Masalah untuk Meningkatkan Kemampuan Berpikir Kritis dan Kreatif Matematik Siswa SMA di Kota Tasikmalaya. Jurnal Pendidikan dan Keguruan Vol. 1 No. 2. 